\title{
Erratum to: Comparison of Residual Stresses in Inconel 718 Simple Parts Made by Electron Beam Melting and Direct Laser Metal Sintering
}

\author{
L.M. SOCHALSKI-KOLBUS, E.A. PAYZANT, P.A. CORNWELL, T.R. WATKINS, \\ S.S. BABU, R.R. DEHOFF, M. LORENZ, O. OVCHINNIKOVA, and C. DUTY
}

DOI: $10.1007 / \mathrm{s} 11661-015-2810-\mathrm{y}$

(C) The Minerals, Metals \& Materials Society and ASM International 2015

\section{Erratum to: METALLURGICAL AND MATERIALS TRANSACTIONS A, VOLUME 46A, MARCH 2015, pp. 1419-1432 DOI: $10.1007 / \mathrm{s} 11661-014-2722-2$}

IN the original article there was an omission in the Acknowledgments. The correct Acknowledgments are as follows:

\section{ACKNOWLEDGMENTS}

Research at ORNL's High Flux Isotope Reactor was sponsored by the Scientific User Facilities Division, Office of Basic Energy Sciences (BES), and U.S. Department of Energy (DOE). Research was also sponsored by: the Laboratory Directed Research and

L.M. SOCHALSKI-KOLBUS, is with the Chemical and Engineering Materials Division, Oak Ridge National Laboratory, One Bethel Valley Rd., P.O. Box 2008, MS 6475, Oak Ridge, TN 37830-475, and also with the Materials Science and Technology Division, Oak Ridge National Laboratory, One Bethel Valley Rd., P.O. Box 2008, Oak Ridge, TN 37830-6430. Contact e-mail: kolbuslm@ornl.gov E.A PAYZANT, Engineering Materials Group Leader, is with the Chemical and Engineering Materials Division, Oak Ridge National Laboratory. P.A. CORNWELL, Scientific Associate, and T.R. WATKINS, Scattering and Thermal Properties Group Leader, are with the Materials Science and Technology Division, Oak Ridge National Laboratory. S.S. BABU, Governor's Chair in Advanced Manufacturing, is with the Manufacturing Demonstration Facility, Oak Ridge National Laboratory, One Bethel Valley Rd., P.O. Box 2008, MS 6479, Oak Ridge, TN 37830-6479, and also with the Department of Aerospace and Biomedical Engineering, University of Tennessee, Knoxville. R.R. DEHOFF, Staff Scientist, and C. DUTY, Senior Staff Scientist, are with the Materials Science and Technology Division, Oak Ridge National Laboratory, and also with the Manufacturing Demonstration Facility, Oak Ridge National Laboratory. M. LORENZ, Scientist, is with the Chemical Sciences Division, Oak Ridge National Laboratory, One Bethel Valley Rd., P.O. Box 2008, MS 6131, Oak Ridge, TN 37830-6131, and also with the National Physics Laboratory, Teddington, U.K. O. OVCHINNIKOVA, Staff Scientist, is with the Chemical Sciences Division, Oak Ridge National Laboratory.

The online version of the original article can be found under doi: 10.1007/s11661-014-2722-2.

Article published online February 24, 2015
Development Program of Oak Ridge National Laboratory (ORNL), managed by UT-Battelle, LLC, for the U. S. DOE; the High Temperature Materials Laboratory at ORNL, sponsored by the Vehicle Technologies Program, Office of Energy Efficiency and Renewable Energy (EERE), U.S. DOE; and the Advanced Manufacturing Office, Office of EERE, U.S. DOE under contract DE-AC05-00OR22725 with UT-Battelle, LLC. M. Lorentz and O. Ovchinnikova acknowledge support by the Division of Chemical Sciences, Geosciences, and Biosciences, Office of BES, U.S. DOE under Contract DE-AC05-00OR22725 with ORNL, managed and operated by UT-Battelle, LLC. The authors would like to thank Alex Fima at Directed Manufacturing Inc. for supplying samples, Fredrick List III and Tom Geer at ORNL and Andrew Kolbus for their technical contributions to this work. 